\title{
1 The State of Research
}

\subsection{On the Concept and Topic of Interreligiosity}

\subsubsection{Defining Interreligiosity}

The increasing religious pluralisation of Austrian society as a consequence of the influx of so-called guest workers already led in the 1980s to intensified discussion on how to deal with non-Christian religions in religious education. ${ }^{1}$ Religious pluralisation, however, at that time fell under the auspices of integration or assimilation education ${ }^{2}$ or intercultural education. ${ }^{3}$ As a result of the legal recognition of the Islamic Religious Community in Austria (Islamische Glaubensgemeinschaft in Österreich [IGGÖ]), the increasing social diversification and growing number of Muslims in Austria led to Islamic religious education being offered in compulsory schools since 1982/83.

Since the 1990s, particularly in the wake of the Yugoslav Wars, many Muslims fled Bosnia and Herzegovina and other Balkan states for Austria, which resulted in a new composition of people with a migration background living in that country. This composition changed again due to the various forced migrations after the end of the Cold War, which were caused by violent political, ethnic, or religiously motivated conflicts. In addition to those who fled from Bosnia and Herzegovina, a great many Muslims also migrated to Austria from Turkey, the Middle East, Arab countries, and North Africa. ${ }^{4}$ These developments also brought a marked rise in Muslims among with a migration background living in Austria and a further differentiation among the Muslim population. ${ }^{5}$

The religious pluralisation of society led, however, not only to the expansion of the range of religious education; it also led to the consequence that didactic

1 Cf. Hellmann, Christian, Religiöse Bildung, Interreligiöses Lernen und interkulturelle Pädagogik. Eine religionsgeschichtliche Untersuchung zur religiösen und interkulturellen Erziehung in der Moderne. Frankfurt/Main 2000, 1f.

2 Cf. Dickopp, Karl-Heinz, Erziehung ausländischer Kinder als pädagogische Herausforderung. Das Krefelder Modell. Düsseldorf 1982.

3 Cf. Auernheimer, Georg, Einführung in die interkulturelle Erziehung. Darmstadt 1990.

4 Cf. Ornig, Nikola, Die Zweite Generation und der Islam in Österreich. Eine Analyse von Chancen und Grenzen des Pluralismus von Religionen und Ethnien. Graz 2006, 165; Heine, Susanne / Lohlker, Rüdiger / Potz, Richard, Muslime in Österreich. Geschichte - Lebenswelt - Religion Grundlagen für den Dialog. Innsbruck 2012, $70 \mathrm{f}$.

5 Cf. Aslan, Ednan / Kolb, Jonas / Yildiz, Erol, Muslimische Diversität. Ein Kompass zur religiösen Alltagspraxis in Österreich. Wiesbaden 2017, 33.

๑ OpenAccess. (c) $2022 \mathrm{Kraml}$, Sejdini, Bauer, Kolb, published by De Gruyter. (cc))BY-NC-ND This work is licensed under the Creative Commons Attribution-NonCommercial-NoDerivatives 4.0 International License. https://doi.org/10.1515/9783110762877-003 
forms, models, and conceptions in religious education were intensively discussed. In addition, in recent decades, the concept of interreligiosity began to move increasingly into the centre of discussion. ${ }^{6}$ In connection with the growing religious pluralisation of West European society, some argued for the rejection of a monolithic understanding of religion in favour of an approach that is possibility-sensitive. ${ }^{7}$ This was considered necessary so that approaches in religious education could adapt to trends in social development. Moreover, in current debates, the concepts of trialogical learning ${ }^{8}$ and transreligiosity are also being discussed as concepts that allow an approach to religion that is contingency-sensitive. ${ }^{9}$

What interreligiosity means will be clarified in this chapter. For an initial approach to the fundamental meaning of the concept, we will first present a conceptual distinction between the terms multireligiosity and transreligiosity.

\section{Interreligiosity and Multireligiosity}

The work of Hans-Georg Ziebertz and Johannes A. van der Ven ${ }^{10}$ can help clarify the distinction between the concepts 'interreligious' and 'multireligious'. ${ }^{11}$ With

6 Cf. Fritsch-Oppermann, Sybille C., Globalisierung als Bedingung interreligiösen Lernens. In: Schreiner, Peter / Sieg, Ursula / Elsenbast, Volker (eds), Handbuch interreligiöses Lernen. Gütersloh 2005, 18-27; Nusser, Barbara, Kebab und Folklore reichen nicht. Interkulturelle Pädagogik und interreligiöse Ansätze der Theologie und Religionspädagogik im Umgang mit den Herausforderungen der pluriformen Einwanderungsgesellschaft. Oldenburg 2005.

7 Cf. Sejdini, Zekirija / Kraml, Martina / Scharer, Matthias, Mensch werden. Grundlagen einer interreligiösen Religionspädagogik und -didaktik aus muslimisch-christlicher Perspektive. Stuttgart 2017, 113; Kraml, Martina, Religionspädagogik im Kontext der Rede von ,transreligiös‘, ,transversal' und ,interreligiös'. In: Sejdini, Zekirija (ed), Islam in Europa. Begegnungen, Konflikte und Lösungen. Münster 2018, 175-194, here 182; Kraml, Martina, Anderes ist möglich. Eine theologiedidaktische Studie zu Kontingenz in Forschungsprozessen. Ostfildern 2019.

8 Cf. Sajak, Clauß Peter (ed), Trialogisch lernen. Bausteine für interkulturelle und interreligiöse Projektarbeit. Seelze 2010; Langenhorst, Georg, Trialogische Religionspädagogik. Interreligiöses Lernen zwischen Judentum, Christentum und Islam. Freiburg 2016.

9 Cf. Sejdini / Kraml / Scharer, Mensch werden, 121-123; Kraml, Religionspädagogik im Kontext der Rede von ,transreligiös‘, ,transversal‘ und ,interreligiös‘, 183; Yildiz, Erol, Ideen zu einer transreligiösen Bildung: Kontrapunktische Betrachtungen. In: Kraml, Martina / Sejdini, Zekirija (eds), Interreligiöse Bildung zwischen Kontingenzbewusstsein und Wahrheitsansprüchen. Stuttgart 2021.

10 Cf. Van der Ven, Johannes A. / Ziebertz, Hans-Georg, Religionspädagogische Perspektiven zur interreligiösen Bildung. In: Ziebertz, Hans-Georg / Simon, Werner (eds), Bilanz der Religionspädagogik. Düsseldorf 1995, 259-273.

11 The term 'multireligious' is used in various distinct ways in theological literature. From both a religious community (e.g., Protestant and Catholic) perspective as well as a liturgical studies 
respect to religious education, Ziebertz and Van der Ven differentiate between three models: the monoreligious, the interreligious, and the multireligious. With the monoreligious form of religious education, they are referring to classical denominational religious education, which is characterised by theological centrism. As a result, according to Ziebertz and Van der Ven, the religion of the denomination itself is often treated as a homogenous and, to all outward appearances, a clearly delineated block. This model therefore makes it quite difficult to come up with an approach to one's own religion that is possibility- and contingency-sensitive. From the authors' point of view, the monoreligious form of education has a tendency, moreover, to approach other types of faith or religions primarily from the inward-looking perspective of their own faith community, without taking the viewpoint of those other religions into account. ${ }^{12}$

Ziebertz and Van der Ven demarcate a multireligious model from the monoreligious one as more akin to religious studies. As far as religious education is concerned, according to them, the goal of such multireligious education is not the search for religious truth or religious knowledge from the participant perspective. Rather, the goal is to understand the differences and correspondences between various religions from the observer perspective. Accordingly, on the one hand, this model goes contrary to the conception of each religion as a monolithic block that defines a fixed entity with clear boundaries. On the other hand, however, the multireligious form of education is also characterised by a philosophical or psychological perspective that displays a tendency toward allegedly objective and abstract valuations. As a result, this model fails to do justice to

one, adherents of different faith communities and religions are, for example, given the opportunity to speak alongside each other or in succession at multireligious celebrations, without engaging in any form of communal prayer. While communal prayer that uses the same wording which can be classified as interreligious - is not considered possible, praying in multireligious fashion beside one another or simply in the presence of others can be endorsed (cf. EKD-Kirchenamt der Evangelischen Kirche in Deutschland [ed], Klarheit und gute Nachbarschaft. Christen und Muslime in Deutschland. Hannover 2006, 115; DBK-Sekretariat der Deutschen Bischofskonferenz [ed], Leitlinien für das Gebet bei Treffen von Christen, Juden und Muslimen. Eine Handreichung der deutschen Bischöfe. Bonn ${ }^{2} 2008$, 33). From the perspective of religious education again, the expression 'multireligious' has a somewhat different meaning. Here, a multireligious form of education is, on the one hand, characterised by the adherents of different faiths taking part in the learning processes while, on the other hand, 'learning about religion' is more akin to non-denominational religious studies and excludes the dimension of religious experiences (cf. Danzl, Clemens, Interreligiös oder multireligiös? In: Kraml, Martina / Sejdini, Zekirija [eds], Interreligiöse Bildungsprozesse. Empirische Einblicke in Schul- und Hochschulkontexte. Stuttgart 2018, 35-47).

12 Cf. Van der Ven / Ziebertz, Religionspädagogische Perspektiven zur interreligiösen Bildung, 265. 
central dimensions of religions - like spirituality or religious experience. ${ }^{13} \mathrm{~A}$ multireligious model of religious education along these lines has been given form in Great Britain, for instance, in the non-denominational subject known as 'Religious Education'. ${ }^{14}$

Ziebertz and Van der Ven then distinguish the interreligious model as a third form in contrast to both of the above types. This model is characterised by active discussions about perspectives in the lessons themselves. In contrast to the monoreligious model, this third model thus follows the principle that the students learn about their own faith not only from the perspective of their own religion but also, so to speak, from the perspectives of other faith communities represented in the course. Consequently, the 'other religion is seen not only through one's own eyes but also through the eyes of others'15. In this model, the boundaries of a religion do not become blurred, as can be case sometimes in the religious studies model. ${ }^{16}$ According to Ziebertz and Van der Ven, however, one's own religion and the other religions are not, as it were, entities to be rigidly defined as clearly demarcated from each other, as often happens in the monoreligious form of education.

\section{Interreligiosity and/or Transreligiosity}

The concepts 'interreligious', 'interreligiosity', or 'interreligious learning' are not, however, unanimously endorsed but are also viewed with scepticism or met with substantive objections from various sides. The reasons for this critical attitude to interreligiosity vary. On the one hand, various doubts are raised by religious institutions that, because of their institutional interests, warn against a mixing of religious traditions and do not welcome interreligious tendencies. On the other hand, the concept of interreligiosity is critiqued with regard to its content. One objection in particular is made to the prefix 'inter'. Because of the construction of the term, according to this criticism, interactions and relations between religions are described that, for their part, could be seen as self-contained and homogenous blocks. Such an understanding would contradict the above-men-

13 Cf. ibid., 264.

14 Cf. Halstead, J. Mark, Islamic Education in the United Kingdom. In: Aslan, Ednan (ed), Islamische Erziehung in Europa. Islamic Education in Europe. Vienna 2009, 179-202.

15 Van der Ven / Ziebertz, Religionspädagogische Perspektiven zur interreligiösen Bildung, 264. 16 On this, cf. also: Jäggle, Martin, Religionen in der Schule - interreligiöser Ansatz oder Religionsunterricht für alle? In: Ucar, Bülent / Blasberg-Kuhnke, Martina / von Scheliha, Arnulf (eds), Religionen in der Schule und die Bedeutung des Islamischen Religionsunterrichts. Göttingen 2010, 179-188. 
tioned fundamental idea of the debate on this, i.e., to point out the similarities and differences between religions and thus to indicate a possibility-sensitive approach. ${ }^{17}$

Instead of 'inter', the prefix 'trans' - following the debate on inter- or transculturality - is preferred. ${ }^{18}$ The term 'transreligiosity' is said to offer the possibility of focusing on the similarities and lines of connection that place religions in relation to each other and exploring them. ${ }^{19}$ But this does not require taking an essentialist point of view in which the religion being discussed appears to be a monolithic block. Rather, a transreligious understanding allows the tendency of religions to change and their porous boundaries to be viewed impartially and as possibility-sensitive. ${ }^{20}$ The concept 'transreligious' can also be interpreted in the sense of something that goes beyond existing religions and leaves them behind. ${ }^{21}$ But a conception of the transreligious is still presupposed, and a systematic elaboration and formulation is needed before the concept can serve as an analytical reference point for empirical research.

Within the framework of this present study, we will use the concept 'interreligious'. We will thus turn to the development of an interreligious religious education because, in our view, it can do the most justice to changing social challenges and the increasing religious pluralism. Moreover, we are also of the opinion that there is a fundamental openness to interreligious tendencies in

17 Cf. Sejdini / Kraml / Scharer, Mensch werden, 121.

18 According to Wolfgang Welsch, transculturality stands diametrically opposed to an essentialist understanding of culture (for a critical approach to essentialism, cf. Fuchs, Stephen, Against Essentialism. A Theory of Culture and Society. Harvard 2001) and pursues instead an approach that is open to alternatives and is contingency-sensitive. In Welsch's view, this does more justice to the external interconnectedness, the internal hybrid character, and the dynamic changes of 'a culture' (cf. Welsch, Wolfgang, Was ist eigentlich Transkulturalität? In: Kimmich, Dorothee / Schahadat, Schamma (eds), Kulturen in Bewegung. Beiträge zur Theorie und Praxis der Transkulturalität. Bielefeld 2012, 25-40). Again, the concept of 'interculturality', cannot satisfy the developmental phenomena of culture because here, in Welsch's view, this concept presupposes interactions between two or more comparatively closed cultural systems (cf. also on this, Langenohl, Andreas, Inter- und Transkulturalität. In: Leggewie, Claus / Meyer, Erik (eds), Global Pop. Das Buch zur Weltmusik. Stuttgart 2017, 54-59).

19 Cf. Faber, Roland, Der transreligiöse Diskurs. Zu einer Theologie transformativer Prozesse. In: polylog (2003) 1, 65-94; Baier, Karl, Transreligiöse Theorie und existentiale Interpretation. In: Interdisziplinäre Phänomenologie (2005) 1, 65-86; Yildiz, Ideen zu einer transreligiösen Bildung.

20 Cf. Sejdini / Kraml / Scharer, Mensch werden, 122; Kraml, Religionspädagogik im Kontext der Rede von ,transreligiös', ,transversal‘ und ,interreligiös', 187.

21 Cf. Baier, Transreligiöse Theorie und existentiale Interpretation. 
Christianity and Islam in the sense that those religions have already fundamentally established and aspired to interreligiosity. ${ }^{22}$

We will not use the concept 'transreligious' within the framework of our analysis, however, because this term has not been sufficiently examined and elaborated in the research to date. But we do avail ourselves of a few aspects from debates connected with the term and do not view religions as self-contained, clearly demarcated entities that interact with each other. We view religions as non-monolithic, unclearly defined entities that are characterised by blurred boundaries, demarcations that are not always clear, and disputed content; they display similarities, interrelationships, and transversal lines of connection.

\subsubsection{The State of Research in Interreligious Religious Education}

Interreligiosity is a recent area of research that has undergone rapidly increasing interest in recent decades. The thematic fields that have been researched are interreligious dialogue, ${ }^{23}$ the religious pluralism of modern societies, ${ }^{24}$ and interreligious education. ${ }^{25}$ This study is situated in the latter - interreligious education - and empirically analyses interreligious collaboration in training religion teach-

22 Cf. Sejdini / Kraml / Scharer, Mensch werden.

23 Cf. among others, Falaturi, Abdoldjavad, Der Islam im Dialog: Aufsätze. Cologne ${ }^{4} 1992$; Neuser, Bernd (ed), Dialog im Wandel. Der christlich-islamische Dialog. Anfänge - Krisen - neue Wege. Neukirchen-Vluyn ${ }^{3}$ 2007; Cornille, Catherine, The Im-possibility of Interreligious Dialogue. New York 2008; Sejdini, Zekirija, Interreligiöser Dialog aus muslimischer Perspektive. In: Gmainer-Pranzl, Franz / Ingruber, Astrid / Ladstätter, Markus (eds), “... mit Klugheit und Liebe” (Nostra aetate 2). Dokumentation der Tagungen zur Förderung des interreligiösen Dialogs 2012-2015 (St. Virgil, Salzburg). Linz 2017, 241-251.

24 Cf. among others, Strutzenberger-Reiter, Edda, Religion in der Schulentwicklung. Eine empirische Studie. Stuttgart 2016; Klutz, Philipp, Religionsunterricht vor den Herausforderungen religiöser Pluralität. Eine qualitativ-empirische Studie in Wien. Münster 2015; Grümme, Bernhard, Heterogenität in der Religionspädagogik. Grundlagen und konkrete Bausteine. Freiburg 2017; Stockinger, Helena, Umgang mit religiöser Differenz im Kindergarten. Eine ethnographische Studie an Einrichtungen in katholischer und islamischer Trägerschaft. Münster 2017.

25 Cf. among others, Leimgruber, Stephan, Interreligiöses Lernen. Munich 2007; Behr, Harry Harun, Yusuf oder Joseph? Eine Probe dialogischer Didaktik in der Lehrerbildung. In: Van der Velden, Frank (ed), Die heiligen Schriften des anderen im Unterricht. Bibel und Koran im christlichen und islamischen Religionsunterricht einsetzen. Göttingen 2011, 221-242; Behr, Harry Harun, Mit dem Vaterunser in den Islamunterricht. In: Van der Velden (ed), Die heiligen Schriften des anderen im Unterricht, 83-101; Schweitzer, Friedrich, Interreligiöse Bildung. Religiöse Vielfalt als religionspädagogische Herausforderung und Chance. Gütersloh 2014; Kraml / Sejdini (eds), Interreligiöse Bildungsprozesse. 
ers as offered at the University of Innsbruck since 2013; it is concerned with the practical implementation of this and focuses in particular on conflicts and tensions that emerge. An analysis of the literature published until now on the theme of interreligious religious education is necessary at this point to situate both the collaboration that occurs and this empirical research accordingly.

In the sections below we will elaborate on the state of research in the field by means of selected publications. We will present these publications in line with the following related fields:

- characteristics of interreligious learning

- fields of application and models of interreligious learning

- empirical studies on the perception of religious difference

- interreligious projects from educational praxis

\section{Characteristics of Interreligious Learning}

Interreligious learning is a constitutive element of interreligious education. ${ }^{26}$ The fundamental substantive purpose of interreligious learning has already been extensively worked out by Folkert Rickers, a religious educationist. Rickers understands interreligious education primarily as 'learning through encounter' be-

26 In general, a distinction is made between three different understandings of education: a material, a formal, and a categorial. In the material theory of education, knowledge alone functions as the absolute standard. Didactically speaking, one conveys as much material as possible. How such conveying occurs is secondary. According to this way of thinking, to be 'educated' means mastering large amounts of material (cf. Jank, Werner / Meyer, Hilbert, Didaktische Modelle. Berlin ${ }^{10} 2011,209$ f.). A formal understanding of education is characterised, in turn, by a focus on the mastery of general methods, which are considered more suitable for the development of the students than simply knowledge of content. Education is thus not approached as the acquisition of knowledge but as the self-education of adolescents (cf. Stübig, Frauke / Stübig, Heinz, Kategoriale Bildung und Kompetenzorientierung. Ist Wolfgang Klafkis Theorie noch zeitgemäß? In: Laging, Ralf / Kuhn, Peter (eds), Bildungstheorie und Sportdidaktik. Ein Diskurs zwischen kategorialer und transformatorischer Bildung. Wiesbaden 2018, 29-48, here 31). The concept of categorial education has in the meantime been developed by Wolfgang Klafki by connecting the elements of the formal and material theories of education to each other in dialectical fashion. Didactically, content should be dealt with primarily in teaching-learning constellations that enable young people to develop fundamental forms and content of knowledge or understanding (cf. Kron, Friedrich W., Grundwissen Didaktik. Munich ${ }^{2} 1994,73$ ). From this perspective, an educated person is one who acquires the intended knowledge and masters the methods of gaining knowledge. 
tween adherents of different religions in school contexts. ${ }^{27}$ According to Rickers, there are five characteristic aspects of interreligious learning.

Spatial conditions are the first aspect he mentions. Religious education in schools offers the most fitting setting, bringing with it the best conditions for interreligious learning. On the one hand, the long-term copresence in such a setting makes interactive encounters and a conversation on questions of faith between adherents of different religions possible. On the other hand, young people in religious education encounter each other in what is for them an ordinary situation that is natural (i.e., not artificial). The basic condition for interreligious learning occurring in religious education is of course that students from different religions participate in it. ${ }^{28}$

A second aspect of interreligious education is found, according to Rickers, in the fact that the material is interdisciplinary in nature, which extends to various educational fields and is not limited exclusively to religious education. ${ }^{29}$ Rickers thus takes a different path from the differentiation proposed by Ziebertz and Van der Ven, ${ }^{30}$ who speak of a separate format of interreligious education and distinguish it from both a monoreligious model and a multireligious model.

As a third characteristic, Rickers introduces the point that interreligious learning is to be understood as a process that the participating adherents of various religions go through on their own. What this requires is a practical encounter and an interactive exchange between participants. ${ }^{31}$ Such independent learning and educational processes can by all means also open up new perspectives on one's own religious heritage. In line with Homi K. Bhabha's concept of 'Third Space, ${ }^{32}$ interreligious learning can be interpreted in such a way that such educational processes open up spaces in which existing knowledge and perspectives on one own religion and that of others can be modified.

27 Cf. Rickers, Folkert, Interreligiöses Lernen. In: Mette, Robert / Id. (eds), Lexikon der Religionspädagogik. Vol. 1: A-K. Neukirchen-Vluyn 2001, 874-881, here 875.

28 Cf. ibid.

29 Cf. ibid.

30 Cf. Van der Ven / Ziebertz, Religionspädagogische Perspektiven zur interreligiösen Bildung. 31 Cf. Rickers, Interreligiöses Lernen, 875.

32 Homi K. Bhabha views the Third Space as above all a place in which cultural differences can be produced and resolved. Third Spaces are thus not tied to a physical location or exist in real space. According to Bhabha, Third Spaces can arise wherever people with different cultural backgrounds and experiences encounter each other. What is central here is that what exists changes, and new content or cultural differences are created (cf. Bhabha, Homi K., The Location of Culture. London 1994, 37). 
Consequently, the basic form of interreligious learning, according to Rickers, is the so-called authentic encounter. ${ }^{33}$ This fourth aspect of such educational processes is characterised by every religion being able to say and assert what it believes. ${ }^{34}$

As the concluding fifth aspect, Rickers mentions that, through this aspect of encounter in interreligious learning, young people can discover a more direct access to 'the world of ideas, experiences, and feelings ${ }^{35}$ of what is for them a strange religion than they can through the study of theological writings or sources.

\section{Fields of Application and Models of Interreligious Learning}

While the necessity and significance of interreligious learning in religious education does not encounter any fundamental resistance for the most part, ${ }^{36}$ the question of what the concrete practice of interreligious educational processes should look like has not been clarified conclusively in any way. We will present some contributions below that have examined concrete applications. Some exemplary studies will be looked at that examine the interreligious religious education in elementary schools both in the university and within the framework of training teachers because our empirical analysis deals with these fields. ${ }^{37}$

33 Cf. Rickers, Interreligiöses Lernen, 875.

34 Cf. Rickers, Folkert, Interreligiöses Lernen. Die religionspädagogische Herausforderung unserer Zeit. In: Id. / Gottwald, Eckart (eds), Vom religiösen zum interreligiösen Lernen. Wie Angehörige verschiedener Religionen und Konfessionen lernen. Möglichkeiten und Grenzen interreligiöser Verständigung. Neukirchen-Vluyn 1998, 119-139, here 126.

35 Rickers, Interreligiöses Lernen, 876.

36 Cf. EKD-Kirchenamt der Evangelischen Kirche in Deutschland (ed), Religionsunterricht für muslimische Schülerinnen und Schüler (Nachdruck des Originals von 1999). In: Schreiner, Peter / Wulff, Karen (eds), Islamischer Religionsunterricht. Ein Lesebuch. Münster 2001, 57-60; Schweitzer, Friedrich, Kooperativer Religionsunterricht: Hindernis oder Voraussetzung interreligiösen Lernens? In: Gottwald, Eckart / Mette, Robert (eds), Religionsunterricht interreligiös. Hermeneutische und didaktische Erschließungen. Festschrift für Folkert Rickers. Neukirchen-Vluyn 2003, 97-108.

37 This is why we do not deal with secondary education. Some important studies, however, are those by Stephan Leimgruber, Andreas Obermann, and Reinhard Kirste, who have examined interreligious educational processes at this level of education (Leimgruber, Interreligiöses Lernen, 108-112; Obermann, Andreas, Religion unterrichten zwischen Kirchturm und Minarett. Entwürfe eines interreligiösen Religionsunterrichts an der Berufsschule. In: Schreiner / Sieg / Elsenbast (eds), Handbuch interreligiöses Lernen, 476-485; Kirste, Reinhard, Interreligiöses Lernen im Sekundarbereich (Sekundarstufe I und II). In: Schreiner / Sieg / Elsenbast (eds), Handbuch interreligiöses Lernen, 465-475). 
Various international empirical investigations took up interreligious educational processes in primary schools in past decades. These studies made different estimations of what interreligious learning could contribute in elementary schools. ${ }^{38}$ In addition to critical voices like that of Barbara Asbrand, ${ }^{39}$ who doubts whether interreligious learning can be done well at the primary level, there are also studies that addressed interreligious models of education in, for instance, the Netherlands or in Great Britain that prove that interreligious learning processes can be realised at this level. ${ }^{40}$

Dietlind Fischer, a religious educationist, indicates four points that are crucial as central aspects of successful interreligious learning.

- First, children in elementary schools should be made religiously literate. What this means is that the students need to be slowly introduced to fundamental religious knowledge, religious rituals, and forms of faith and spirituality. ${ }^{41}$ Consequently, children at this level should not be treated in any way as experts in their own religion. ${ }^{42}$ Rather, one should keep in mind in this context - and Ulrike Lingen-Ali and Paul Mecheril in particular point to this - that children at the elementary school level should not be defined too strictly as having a particular religious affiliation by the teacher and

38 A strict comparison of the differing models of education in elementary schools would necessitate taking into account other parameters - such as the existence of a state church (in Great Britain) or a laic relation between state and religion (in the Netherlands). We will not attempt such a comparison. Instead, we will suffice with the indication that there are well-tested educational models with an interreligious orientation that differ from each other on the basis of their different constitutions and legal conditions.

39 Asbrand, Barbara, Zusammen Leben und Lernen im Religionsunterricht. Eine empirische Studie zur grundschulpädagogischen Konzeption eines interreligiösen Religionsunterrichts im Klassenverband der Grundschule. Frankfurt/Main 2000.

40 Cf. Grimmitt, Michael / Grove, Julie / Hull, John / Spencer, Louise, A Gift to the Child. Religious Education in the Primary School. London 1991; Hull, John, How can we make children sensitive to the values of other religions through religious education? In: Lähnemann, Johannes (ed), Das Projekt Weltethos in der Erziehung. Hamburg 1995, 301-314; ten Broek, Bart, Die interkulturelle und interreligiöse Juliana van Stolbergschule in Ede in den Niederlanden. In: Rickers, Folkert / Siedler, Dirk C. (eds), Interreligiöses Lernen in den Niederlanden. Ein Beitrag zur Vergleichenden Religionspädagogik. Berlin 2001, 11-19; Dommel, Christa, Interreligiöses Lernen im Elementarbereich: Kindertagesstätten und Kindergärten. In: Schreiner / Sieg / Elsenbast (eds), Handbuch interreligiöses Lernen, 434-452, here 445-451.

41 Cf. Fischer, Dietlind, Interreligiöses Lernen in der Grundschule. In: Schreiner / Sieg / Elsenbast (eds), Handbuch interreligiöses Lernen, 453-464, here 455.

42 Cf. ibid., 460. 
'no religious identity in the sense of essential one [should be] attributed to them. ${ }^{, 43}$

- In addition to religious literacy, familiarisation with the differences between religions is required. This should be done along the lines of the model of religious studies. ${ }^{44}$

- As a third aspect, Fischer concretises the content that is to be offered for interreligious learning in primary schools. She suggests the themes of religious celebrations, founders of religions, the patriarchal narratives of Abraham/ Ibrahim, dying and death, the exploration of sacred sites, sacred scriptures, and creation myths. She proposes these areas because concrete observation, experience, and analysis and knowledge acquisition can be made possible through each of these. ${ }^{45}$

- The question as to how these themes can be implemented in didactic practice brings us to the fourth aspect. Fundamentally, according to Fischer, teaching methods must meet the criteria that they be stimulating, multifaceted, and realistic. ${ }^{46}$ Here, one can think of visits to places where the religion in question is practised, meetings with adherents of various faith communities, participation in religious celebrations or the practice of living rituals. But above all, it comes down to getting children to participate in the education event, to learn independently by enabling them to design education praxis and allowing choices in the encounter with the religious other. ${ }^{47}$ Such didactic approaches that are realistic, multifaceted, and stimulating are very different from the instructionist approaches that, in line with the example of frontal teaching, certainly demote students into passive receptors of pre-packaged knowledge.

In addition to elementary education, the education of religion teachers at the university also represents a field of activity for interreligious collaboration. The curricula of teachers' education at universities in regions, particularly in states and federal provinces that provide a confessional or monoreligious religious education, ${ }^{48}$ often display shortcomings in interreligious learning. That is why Ul-

43 Linger-Ali, Ulrike / Mecheril, Paul, Religion als soziale Deutungspraxis. In: Österreichisches Religionspädagogisches Forum (2016) 2, 17-24, here 22.

44 Cf. Fischer, Interreligiöses Lernen in der Grundschule, 459.

45 Cf. ibid., 460.

46 Cf. ibid., 461.

47 Cf. ibid.

48 While confessional religious instruction is given throughout the Austrian provinces, offered by various recognised religious communities, the situation in Germany is different. For example, 
rike Baumann argues that elements of interreligious education should be offered in university theological faculties to ensure that religion teachers have a minimum basic knowledge of other religions. Moreover, it should also be a goal to have teachers of religion who are actively teaching in the schools 'gradually expand their knowledge of other religions in the form of continuing education. ${ }^{39}$ For such a dialogical motivation to be employed among teachers at all, however, interreligious learning already needs to have a place in their training at university. ${ }^{50}$ Karl Ernst Nipkow therefore argues that religious education at the university - also in the sense of a 'migration education'51 - 'should be done in a more strongly analytical and empirical way in the intercultural context'52.

With a view to the encounter between Christianity and Islam, Baumann captures the following themes as areas of learning that are of special significance for educational requirements in religious educational training: the relation between the Bible and the Qur'an, the belief in one God, the concept of humanity, ethical questions, and views of education. ${ }^{53}$

The didactic and methodological question of how to implement interreligious learning in the training and continuing education of religion teachers is still a neglected field, however.

\footnotetext{
in Hamburg and Bremen, where 'religious education for all' or the subject 'Religion' is an element of the school curriculum, interreligious learning is already a constitutive feature in the education of teachers of religion from the ground up (cf. Weiße, Wolfram, Der Hamburger Weg eines dialogischen "Religionsunterrichts für alle" im Kontext gegenwärtiger Debatten. Eine Einführung. In: Id. [ed], Dialogischer Religionsunterricht in Hamburg. Positionen, Analysen und Perspektiven im Kontext Europas. Religionen im Dialog - Vol. 2. Münster 2008, 9-18; Lott, Jürgen / Schröder-Klein, Anita, Religion unterrichten in Bremen. In: Theo-Web. Zeitschrift für Religionspädagogik [2006] 1, 68-79).

49 Baumann, Ulrike, Interreligiöses Lernen in der Aus- und Fortbildung von Pädagoginnen und Pädagogen. In: Schreiner / Sieg / Elsenbast (eds), Handbuch interreligiöses Lernen, 533-542, here 534 .

50 Cf. Haußmann, Werner, Universität und Lehrerausbildung als Orte interreligiösen Lernens. In: Schreiner / Sieg / Elsenbast (eds), Handbuch interreligiöses Lernen, 508-519, here 516.

51 Cf. Mecheril, Paul, Migrationspädagogik - ein Projekt. In: Id. (ed), Handbuch Migrationspädagogik. Weinheim 2016, 8-30.

52 Nipkow, Karl Ernst, Multikulturelle und multireligiöse Erziehung in der Schule. In: Zeitschrift für Pädagogik und Theologie (2002) 2, 101-118, here 117.

53 Cf. Baumann, Interreligiöses Lernen in der Aus- und Fortbildung von Pädagoginnen und Pädagogen, 536-540.
} 


\section{Empirical Studies on the Perception of Religious Difference}

In this section we will look at studies that investigate interreligious learning in educational contexts that have still not been mentioned in our discussions above. We should emphasise here the work of Andrea Betz on the spread of prejudices and stereotypes regarding religious difference among students ${ }^{54}$ as well as the analyses that occurred in the research project REDCo coordinated by Wolfram Weiße. ${ }^{55}$

In her study, Andrea Betz deals empirically with questions that are connected to interreligious learning and also play an important role in our research. She thus focuses on prejudices and stereotypes towards the religious other among aspiring religion teachers. In her empirical study, which was published in the spring of 2018, Betz discusses in detail the connection between interreligious educational processes and prejudices towards the religious other and their mutual relation.

The study is based on an empirical survey in which aspiring religion teachers in Würzburg and Munich (sample size $\mathrm{N}=557$ ) had participated by means of a quantitative questionnaire. Here it was shown, among other things, that the confrontation with genuine theological themes in particular can lead to reflection processes that promote an open approach to religious diversity and pluralism. ${ }^{56}$ Moreover, in her research, Betz discovered prevalent critical attitudes among Christians regarding Islam. This finding corresponds with the results from other research. The Pew Research Center, for example, came to approximately the same conclusion, i.e., that Christians are sometimes strongly prejudiced against Muslims or immigrants than adherents of other religions or secular people are. ${ }^{57}$ But, according to Betz, these attitudes resulted primarily from the fact that the respondents to the questionnaire themselves practised an individualistic religion and therefore rejected an authoritarian form of religiosity that

54 Cf. Betz, Andrea, Interreligiöse Bildung und Vorurteile. Eine empirische Studie über Einstellungen zu religiöser Differenz. Berlin 2018.

55 Cf. Knauth, Thorsten / Jozsa, Dan-Paul / Bertram-Troost, Gerdien / Ipgrave, Julia (eds), Encountering Religious Pluralism in School and Society. A Qualitative Study of Teenage Perspectives in Europe. Münster 2008; Weiße, Wolfram, Interreligiöse Bildung in Europa. Neue Entwicklungen in der öffentlichen Debatte, in der Forschung und im Trialog an Schulen. In: Sajak (ed), Trialogisch lernen, 25-39; Valk, Pille / Bertram-Troost, Gerdien / Friederici, Markus / Béraud, Céline (eds), Teenagers' perspectives on the role of religion in their lives, schools and societies. A European quantitative study. Münster 2009.

56 Cf. Betz, Interreligiöse Bildung und Vorurteile, 263.

57 Pew Research Center (ed) 2018: Christ sein in Westeuropa. In: http://assets.pewresearch.org/ wp-content/uploads/sites/11/2018/05/24143201/Being-Christian-in-Western-Europe-FINAL-GERMAN.pdf, 10, [last accessed on 10.09.2018]. 
they assume Muslim believers have. The study also showed that, for the manifestation of stereotypes, prejudices, and derogatory attitudes toward the religious other, it is not exclusively personal faith and the expression of religiosity that are decisive but, stronger, cultural, ideological, historical, social, and/or political factors also play a role. ${ }^{58}$

In addition to Betz' study, we will now look at the large-scale REDCo ${ }^{59}$ project led by Wolfram Weiße, which, between 2006 and 2009, investigated how religious education in schools in eight different European countries contributed to dialogue between different population groups (religious, ethnic, cultural, or social). ${ }^{60}$ This project analyses to what extent adolescents between 14 and 16 years old perceive religious plurality as a starting point for dialogue or as a possible flash point. In addition to a qualitative research section, this mixed methods study also included a quantitative survey that showed adolescents often deliberately avoid religious or cultural heterogeneity in their circle of friends and acquaintances and have few experiences with other religions. In the school context, this means that a religiously heterogeneous composition of students would not lead necessarily to interreligious contacts or encounters. Thus, an encounter with the religious other does not occur within the peer group or in the context of leisure activities but primarily in religious education in the school. ${ }^{61}$ Given this, according to the participating researchers, religious education thus played a crucial role in interreligious exchange and in the pupils becoming acquainted with religious difference. ${ }^{62}$

Furthermore, the quantitative analyses proved that - when religious difference is thematised - adolescents see the right to freedom of religion and the equality of religions as self-evident, while exclusive religious truth claims or missionary approaches are rejected. Moreover, it becomes clear in the data - similar to what we saw in Andrea Betz' study - that prejudices against Islam exist, particularly among Christian students. In general, however, according to the authors of this study, these prejudices did not stem from personal experiences but usu-

58 Cf. Betz, Interreligiöse Bildung und Vorurteile, 267.

59 REDCo is an acronym for the title of the project: 'Religion in Education. A Contribution to Dialogue or a Factor of Conflict in Transforming Societies of European Countries'.

60 Cf. Jozsa, Dan-Paul / Knauth, Thorsten / Weiße, Wolfram, Religion in der Schule. Eine Vergleichsstudie zwischen Hamburg und Nordrhein-Westfalen. In: Eaed. (eds), Religionsunterricht, Dialog und Konflikt. Analysen im Kontext Europas. Münster 2009, 199-240.

61 Cf. Jozsa, Dan-Paul, Religious Education in North-Rhine Westphalia: Views and Experiences of Students. In: Knauth / Id. / Bertram-Troost / Ipgrave (eds), Encountering Religious Pluralism in School and Society, 173-206, here 194.

62 Cf. Weiße, Interreligiöse Bildung in Europa. 
ally from media coverage on the themes of Islam and Muslims. Contact and experiences with the religious other led, as a rule, to a reduction of religious prejudice and reservations regarding religious difference. ${ }^{63}$

Following qualitative surveys, the insights into the perception of religious difference by young people could be explored further within the framework of the REDCo project. Group interviews revealed that contextual factors that were not connected to religious education decisively shape the perception of religious difference. Thus, among young people who come from a non-religious background, the confrontation with religious minorities in religious education can lead to even less understanding instead of tolerance. In turn, in areas stamped by religion, according to the authors, faith or religiosity is secondary and almost negligible in their treatment of their fellow students. ${ }^{64}$

Altogether, the empirical findings of the research project show that, among students, the internalisation of tolerance takes shape as a socially desirable form of dealing with religious difference. For the most part, however, this attitude is not rooted in their own practical everyday life, for the adolescents in the peer group have few intersection points with those of other faiths. ${ }^{65}$ The trend among non-religious people is that religious difference can lead to conflict, whereas students who are more religious have a more open attitude to the religious other. At the same time, however, the latter tend to want to convince those of other faiths that their own religious views are correct. ${ }^{66}$

Taken together, the empirical analyses that were carried out within the REDCo project provide detailed insight into the range of perceptions of religious difference among students in various European educational contexts. To what extent these attitudes can change, develop, or become stronger in the course of interreligious learning was not examined in the research project. In the following section, we will present studies investigating these questions.

63 Cf. Jozsa, Dan-Paul / Friederici, Markus, European Comparison: Personal Views and Experiences of Religion. In: Knauth / Jozsa / Bertram-Troost / Ipgrave (eds), Encountering Religious Pluralism in School and Society, 375-388.

64 Cf. Ipgrave, Julia, Relationships between local patterns of religious practice and young people's attitudes to the religiosity of their peers. In: Journal of Beliefs \& Values (2012) 3, 261-274. 65 Cf. Jozsa / Knauth / Weiße, Religion in der Schule.

66 Cf. Béraud, Céline, The role of religion in students' lives and their surroundings. In: Valk / Bertram-Troost / Friederici / Ead. (eds), Teenagers' perspectives on the role of religion in their lives, schools and societies, 397-408. 


\section{Interreligious Projects from Pedagogical Praxis}

This section will provide insight into interreligious projects that have already been implemented in (religious) pedagogical praxis and have been empirically researched or followed. ${ }^{67}$ We will introduce a project that was initiated and supervised by the research group headed up by Friedrich Schweitzer and Reinhold Boschki, ${ }^{68}$ as well as a current project by the University College of Teacher Education of Christian Churches Vienna/Krems (Kirchliche Pädagogische Hochschule; KPH). ${ }^{69}$ In connection with this, we will also mention a project by the religious educator Wolfgang Weirer at the University of Graz. ${ }^{70}$

The first study, which empirically examines the implementation of an interreligious education project, was carried out by Friedrich Schweitzer, Magda Bräuer, and Reinhold Boschki. This study, which represents the results of a research project that ran from 2013-2017, was concerned primarily with the effectiveness and learning success of interreligious learning. ${ }^{71}$ The learning success is defined in terms of the extent to which religious competences or the willingness to adopt perspectives related to religion ${ }^{72}$ are promoted and religious attitudes undergo further development. To investigate the effects of pedagogical approaches, an intervention study was chosen. Altogether, a sample of $\mathrm{N}=1,105$

67 Cf. Kolb, Jonas, Modes of Interreligious Learning within Pedagogical Practice. An Analysis of Interreligious Approaches in Germany and Austria. In: Religious Education (2021) 2, 142-156, https://doi.org/10.1080/00344087.2020.1854416.

68 Cf. Schweitzer, Friedrich / Bräuer, Magda / Boschki, Reinhold (eds), Interreligiöses Lernen durch Perspektivenübernahme. Eine empirische Untersuchung religionsdidaktischer Ansätze. Münster 2017.

69 Cf. Garcia Sobreira-Majer, Alfred / Abuzahra, Amani / Hafez, Farid / Ritzer, Georg, Interreligiöses Lernen in Begegnung - Evaluation von Begegnungslernen in der ReligionslehrerInnenausbildung. In: Krobath, Thomas / Ritzer, Georg (eds), Ausbildung von ReligionslehrerInnen. Konfessionell - kooperativ - interreligiös - pluralitätsfähig. Vienna 2014, 155-184; Garcia Sobreira-Majer, Alfred, “Das Kennenlernen des Fremden baut Vorurteile ab”. Interreligiöse Studierenden-Begegnungen an der KPH Wien/Krems und der IRPA. In: Schluss, Henning / Tschida, Susanne / Krobath, Thomas / Dansgen, Michael (eds), Wir sind alle "andere". Schule und Religion in der Pluralität. Göttingen 2015, 139-144.

70 Cf. Eklaude, Dagmar, Koran in der Klasse. In: Unizeit. Das Forschungsmagazin der Karl-Franzens-Universität Graz (2018) 2, 8-9.

71 Cf. Schweitzer / Bräuer / Boschki (eds), Interreligiöses Lernen durch Perspektivenübernahme. 72 The adoption of perspectives is understood in this study to refer to the extent to which the people surveyed are inclined to enter into the viewpoints of people who adhere to another religion. The measure for this exchange of perspectives is the self-description or self-perception of the person surveyed (cf. Schweitzer, Friedrich, Interreligiöse Kompetenz: Stand der Diskussion Aufgaben der Forschung - Ausgangspunkte für die empirische Untersuchung. In: Schweitzer / Bräuer / Boschki (eds), Interreligiöses Lernen durch Perspektivenübernahme, 56-69, here 66f.). 
students could be reached in the study. The survey was done in classes of the first- and second-year students at commercial vocational schools in the federal state of Baden-Württemberg in Germany. During the study, two educational modules were developed that deal with the themes 'Religion and Violence'73 and 'Islamic Banking'74. Each block had six units and included components in which the acquisition of knowledge, the practice of adopting perspectives, and the examination of one's own and others' values was made possible. ${ }^{75}$

After various pretests, the educational blocks were implemented in a series of school classes (experimental groups). Subsequently, empirical analyses were done with inputs from questionnaire surveys in which both the students of the experimental group participated as well as school classes where the educational units were not implemented (control group). ${ }^{76}$ Given this research design, the study leaders investigated the extent to which the interventions led to an increase or change in interreligious competences as well as to an adoption of perspectives related to religion by comparing the experimental group and the control group.

The findings of the empirical study showed that participation in the educational units developed clearly promoted training in religious knowledge and the corresponding competences. An adoption of religious perspectives occurred only in a few cases, however. ${ }^{77}$ Study results led to the conclusion that interreligious learning in religious education can show effects that can be clearly traced empirically. The educational unit 'Islamic Banking' in particular did not lead to any increase in interreligious competence or to an adoption of religion-related perspectives among the prospective bankers. But it became clear that there is no necessary connection between learning success and a didactic approach oriented to the life situation of the students. This finding puts into question the wide-

73 Cf. on this Gronover, Matthias / Schnabel-Henke, Hanne, Möglichkeiten der didaktischen Umsetzung - Einführung in die Unterrichtseinheiten. In: Schweitzer / Bräuer / Boschki (eds), Interreligiöses Lernen durch Perspektivenübernahme, 70 - 80, here 77-80; Gronover, Matthias / Hiller, Simone, Religionen und Gewalt. In: Schweitzer / Bräuer / Boschki (eds), Interreligiöses Lernen durch Perspektivenübernahme, 186-232.

74 Cf. on this Gronover / Schnabel-Henke, Möglichkeiten der didaktischen Umsetzung, 72-76; Märkt, Claudia / Schnabel-Henke, Hanne, Islamic Banking - Zum Umgang mit Geld in Christentum und Islam. In: Schweitzer / Bräuer / Boschki (eds), Interreligiöses Lernen durch Perspektivenübernahme, 147-185.

75 Cf. Gronover / Schnabel-Henke, Möglichkeiten der didaktischen Umsetzung, 72.

76 Cf. Schweitzer, Friedrich / Bräuer, Magda / Losert, Martin, Einführung und zusammenfassende Darstellung des Forschungsprojekts. In: Schweitzer / Bräuer / Boschki (eds), Interreligiöses Lernen durch Perspektivenübernahme, 11-29, here $18 \mathrm{f}$.

77 Cf. ibid., 24. 
spread assumption that a realistic relation to one's lifeworld should be a condition for learning success. ${ }^{78}$ Furthermore, this empirical study showed that participation in interreligious modules did not have compulsory effects on the level of attitude. Thus, after they expanded their knowledge of Islamic banking or of the relation between religions and violence as a result of the educational units, the student turned out to be neither significantly more open to nor more hostile to the religious other than before the intervention. ${ }^{79}$

In addition to the interreligious project of the research group led by Schweitzer and Boschki, we should emphasise an initiative by the University College of Teacher Education of Christian Churches Vienna/Krems (KPH) to promote encounters between Muslim and Christian students. ${ }^{80}$ This project pursued the aim 'of making students capable of facilitating interreligious learning processes in their future professional field as teachers of religion's1. Like the project described above, in the approach at KPH Vienna/Krems, the interreligious processes were not only initiated and implemented but also scientifically monitored and evaluated.

The approaches of Stephan Leimgruber and Folkert Rickers, who stressed the encounter character of interreligious learning ${ }^{82}$ and the centrality of a dialogue with the religious other, ${ }^{83}$ functioned as the theoretical framework. Borrowing from the model of religious competences, ${ }^{84}$ the results of processes of interreligious encounter were moored to four dimensions: 'interest in the other religion', 'knowledge of other religions', 'tolerance' and 'the capacity for adopting other perspectives'. ${ }^{85}$ Several meetings were conducted in which Muslim and Christian students participated and dealt together with substantive questions on

78 Cf. ibid., 29.

79 Cf. Schweitzer, Friedrich / Boschki, Reinhold, Zur Bedeutung der Befunde - Konsequenzen für religionsdidaktische Forschung und religionspädagogische Theoriebildung. In: Schweitzer / Bräuer / Boschki (eds), Interreligiöses Lernen durch Perspektivenübernahme, 133-138, here $134-138$.

80 The encounters were done at a time when the private programmes for the teaching post for Islamic Religion at Compulsory Schools (Islamische Religion an Pflichtschulen; IRPA) in Vienna had still not been integrated into KPH Vienna/Krems. This step was taken in 2016.

81 Garcia Sobreira-Majer / Abuzahra / Hafez / Ritzer, Interreligiöses Lernen in Begegnung, 155.

82 Cf. Leimgruber, Interreligiöses Lernen, 101.

83 Cf. Rickers, Interreligiöses Lernen, 875.

84 Cf. Willems, Joachim, Interreligiöse Kompetenz. Theoretische Grundlagen - Konzeptualisierungen - Unterrichtsmethoden. Wiesbaden 2011; Schambeck, Mirjam, Interreligiöse Kompetenz. Basiswissen für Studium, Ausbildung und Beruf. Göttingen 2013.

85 Cf. Garcia Sobreira-Majer / Abuzahra / Hafez / Ritzer, Interreligiöses Lernen in Begegnung, 157. 
the theme of ethics or with the significance of Abraham/Ibrahim (from Christian and Islamic perspectives).

The meetings were evaluated on the one hand via a quantitative questionnaire that operationalised the various dimensions of interreligious competences and that the participating students filled in both before and after the meeting. A control group, which did not take part in the meeting, was also surveyed. Following the quantitative survey, qualitative focus groups were conducted where participants reflected on the experiences garnered in the interreligious encounter. Focus groups were made up of two to five people from the same religion. ${ }^{86}$

It became clear in the analysis that the encounters heightened awareness as well as facilitated learning experiences and growth in knowledge concerning the religious other as well as one's own religion. It was also clear from the empirical data that the interreligious encounter did not lead to saturation but to an increase in interest in the religious other. Moreover, the participants reflected the fact that their earlier ideas of the religious other were mostly influenced by negative media reports. ${ }^{87}$ During the meetings, such negative prejudices or distorted clichés decreased. Those attitudes were replaced by one of tolerance and respect for the religious other ${ }^{88}$ It was also shown that many of the participating students became capable of adopting a different perspective related to religion and permitted themselves 'to enter into the other "faith world".,89

Another project that observes and studies concrete interreligious learning in pedagogical praxis is the research project at the University of Graz supervised by Wolfgang Weirer called 'Integration through Interreligious Education' ('Integration durch interreligiöse Bildung'). In addition to quantitative surveys, which investigated 1,300 school administrations and analysed the current state of Islamic religious education in the Austrian regions of Styria and Carinthia, interreligious units were designed for both the elementary and secondary levels I and II. ${ }^{90}$ That project aims at setting up a continuing education programme for Islamic religion teachers. $^{91}$

An overall view of the state of research clearly shows that, in the analysis of interreligious educational processes until now, there were some one-sided em-

86 Cf. ibid., $159 \mathrm{f}$.

87 Cf. ibid., $180 \mathrm{f}$.

88 Cf. Garcia Sobreira-Majer, "Das Kennenlernen des Fremden baut Vorurteile ab".

89 Garcia Sobreira-Majer / Abuzahra / Hafez / Ritzer, Interreligiöses Lernen in Begegnung, 181.

90 Cf. Eklaude, Koran in der Klasse.

91 Cf. Institut für Katechetik und Religionspädagogik der Universität Graz (ed), Islamischer Religionsunterricht im Süden Österreichs: Präsentation der ersten Studienergebnisse. Press release, March 22, 2018. 
phases. There is, indeed, no lack of programmatic works and the implementation of different approaches to interreligious learning at various levels and educational contexts has already occurred. Be that as it may, however, the analysis of content, the planning of concrete educational processes, the process of interreligious learning, as well as the engagement with the participating actors has suffered from a lack of attention until now.

In this study, we therefore focus on one of these gaps in the research. We will concern ourselves with the actors who are participants in the processes of interreligious learning and encounter during their education as religion teachers. In particular, in our analysis we will emphasise the conflicts and the various points of conflict potential that emerge between the actors or groups.

Fundamentally, the theme of conflict requires a deep attentiveness, for until now it has not been the focus of research and in works on interreligious learning. In programmatic works, however, hypotheses on conflicts are already posed in theory. Those hypotheses point to the relevance of this issue. ${ }^{92}$ The questions of which conflicts exist in interreligious educational processes and which conflicts play a relevant role or only arise in the course of such processes have been neglected in research on interreligious processes until now. For this reason as well, we focus in this study on the systematic investigation of conflicts, fields of tension, and their elements in processes of interreligious learning.

To answer the question of what can be understood concretely by conflict or an area of conflict, in the section below we will examine the relation between the concepts of religion and conflict. Starting with the analysis of selected works that are concerned with this relation, in chapter $\mathbf{2}$ we will subsequently develop proposals for understanding conflict in the context of our empirical study.

\subsection{The Relation between Religion and Conflict: Research Trends}

We cannot omit the multifaceted thematic area 'Religion and Conflict' from this volume. Nevertheless, this is a wide field that is discussed in the most varied sciences in disparate and sometimes also controversial ways - especially from the theological perspective of (monotheistic) religions. The purpose of this section is

92 Cf. Nipkow, Karl Ernst, Ziele interreligiösen Lernens als mehrdimensionales Problem. In: Schreiner / Sieg / Elsenbast (eds), Handbuch interreligiöses Lernen, 362-380, here 364; Schweitzer, Interreligiöse Bildung, 60. 
to provide insights into social-scientific, political, and religious studies discourses.

The nature of and ways in which the debate about Muslims and Islam is conducted today can be seen in the 2018 book by the controversial German author and politician Thilo Sarrazin: Feindliche Übernahme. Wie der Islam den Fortschritt behindert und die Gesellschaft bedroht ('Hostile Takeover: How Islam Hinders Progress and Threatens Society'). ${ }^{93}$ Aside from its failings in content, the book refers to a recent discourse that gives rise to a conflict-charged socio-political atmosphere by means of imputations and generalities accepted in any case by politically right-wing actors. Moreover, the author takes up arguments that are not new and are even long outdated in cultural studies. Religion, here Islam, is equated with violence, danger, and conflict. Here, it needs to be demonstrated that a connection between conflict and Islam is to be rejected a priori, that religions per se do not promote violence nor lead to conflict.

While we should not dismiss the claim that a conflict potential exists both within religions as well as between them, this requires a detailed scientific analysis on macro-, meso-, and microlevels. In this chapter we will therefore present the state of research and trends in research on the relation between religion and conflict in various disciplines in order to lay a foundation for our empirical analysis in this book. In what follows, we will refer first to religion and conflict from the social-scientific perspective, in order to then discuss the relation between both concepts from the viewpoint of religious studies, theology, and religious education.

\subsubsection{Religion and Conflict as a Social-Scientific Research Topic}

\section{Peace and Conflict Research}

The theme of conflict as a subject of research has attracted interest in recent years in various academic disciplines. Conflicts are analysed from different perspectives and numerous theories for understanding conflicts are developed especially in political science and the social sciences, but also in psychology, cultural studies, theology, history, as well as numerous natural sciences. ${ }^{94}$

In the latter half of the $20^{\text {th }}$ century, the macrosocial confrontation with conflict led to the emergence of interdisciplinary peace and conflict research. On the

93 Sarrazin, Thilo, Feindliche Übernahme: Wie der Islam den Fortschritt behindert und die Gesellschaft bedroht. Munich 2018.

94 An overview of the various theories about conflict from a psychological or a social science perspective can be found in chapter 2.2. 
one hand, this research pursued the normative claim of placing the 'value of peace above other interests, ${ }^{95}$ and, on the other, wanted to contribute to the analysis of conflict- or peace-promoting processes. Topics of research include various social conflict constellations, such as population trends and conflict dynamics, ${ }^{96}$ social gender relations or labour relations as a field of conflict, ${ }^{97}$ as well as conflict analysis related to terrorism, fundamentalism, war and genocide, or energy conflicts as a consequence of climate change. ${ }^{98}$ Since their establishment in the late 1950s, interdisciplinary research centres have developed in Europe and around the world ${ }^{99}$ that carry out various prioritisations of conflict research. More recent approaches in conflict and peace research deal with the critical analysis of social processes for the formation of elites and the economic conditions that lead to inequality, migration, flight, or death. ${ }^{100}$

The research on conflict is concerned on the one hand with sociological and psychological characterisations of conflicts. Here, psychological models and social-scientific theories of conflict are consulted. On the other hand, causes, factors, and possible functions of conflicts and their course are researched, as well as solutions and intervention strategies derived from them. ${ }^{101}$ Religion(s) as a factor in and cause of conflicts and/or their solutions are only implicitly thematised in peace and conflict research - for example, in the framework of analysing Islamic fundamentalism or migration ${ }^{102}$ - and are hardly taken into account in the thematic fields mentioned.

95 Koppe, Karlheinz, Zur Geschichte der Friedens- und Konfliktforschung im 20. Jahrhundert. In: Imbusch, Peter / Zoll, Ralf (eds), Friedens- und Konfliktforschung. Eine Einführung. Wiesbaden ${ }^{5} 2010,17-66$, here 17.

96 Cf. Bös, Matthias, Konfliktdynamiken der Bevölkerungsentwicklung in Deutschland nach dem Zweiten Weltkrieg. In: Imbusch / Zoll (eds), Friedens- und Konfliktforschung, 383-404. 97 Cf. Kißler, Leo, Arbeitsbeziehungen - Die ,Konfliktpartnerschaft‘ zwischen Kapital und Arbeit. In: Imbusch / Zoll (eds), Friedens- und Konfliktforschung, 459-484; Sturm, Gabriele, Das gesellschaftliche Geschlechterverhältnis als Konfliktfeld. In: Imbusch / Zoll (eds), Friedensund Konfliktforschung, 405-440.

98 A compilation of some systematic analyses of conflicts is to be found in Imbusch / Zoll (eds), Friedens- und Konfliktforschung, 221-354.

99 Cf. Koppe, Zur Geschichte der Friedens- und Konfliktforschung im 20. Jahrhundert, 31.

100 Cf. ibid., 54.

101 Cf. Simon, Fritz B., Einführung in die Systemtheorie des Konflikts. Heidelberg ${ }^{3} 2015$.

102 For a short overview of the themes of migration and Islamic fundamentalism in peace and conflict research see Ruf, Werner, Islamischer Fundamentalismus. In: Imbusch / Zoll (eds), Friedens- und Konfliktforschung, 309-332; Nuscheler, Franz, Migration als Konfliktquelle und internationales Ordnungsproblem. In: Imbusch / Zoll (eds), Friedens- und Konfliktforschung, 273286. 
The neglect of religious themes in social-scientific studies - thus also in peace and conflict research - is conditioned, according to the political scientist Mathias Hildebrandt, by the endorsement of the 'secularisation thesis' of social scientists. As a result,

the influence of religion(s) or religious phenomena on political and social acts of people, social organisations, and national or political entities in the processes of world history [is being] increasingly marginalised. ${ }^{103}$

This topos of secular modernity experienced radical upheavals not least because of events like the Islamist-motivated attacks on the World Trade Center in New York and the Pentagon in Washington DC on 9/11. Because of the violent acts of religiously motivated actors, the 'invisible religion'104 that Luckmann signalled became a visible expression of a new paradigm concerning the social relevance of religious themes.

The potential of religion(s) for violence and conflict has since then taken on a special focus in social-scientific publications, and it 'indicates a general abandonment of the secularisation paradigm, ${ }^{105}$. Altogether, this development in the sciences - including theology and religious education - is a subject of controversial discussion.

\section{The Political Dimension of Religion and Conflict}

Several publications place this conflict-enhancing and violent aspect of religion front and centre, such as the above-mentioned volume edited by Mathias Hildebrandt and Manfred Brocker, Unfriedliche Religionen? Das politische Gewalt- und Konfliktpotential von Religionen ('Non-Peaceful Religions? The Potential of Religions for Political Violence and Conflict'). ${ }^{106}$ The first part of this book discusses the potential for violence and conflict in political theologies by means of the examples of Islamism, ${ }^{107}$ Marxism, nationalism, ${ }^{108}$ as well as the general potential

103 Hildebrandt, Mathias, Einleitung: Unfriedliche Religionen? Das politische Gewalt- und Konfliktpotenzial von Religionen. In: Id. / Brocker, Manfred (eds), Unfriedliche Religionen? Das politische Gewalt- und Konfliktpotenzial von Religionen. Wiesbaden 2005, 9-38, here 9.

104 Ibid.

105 Ibid.

106 Hildebrandt / Brocker (eds), Unfriedliche Religionen?

107 Cf. Jung, Dietrich, ,Der Islam gegen den Westen'. Zur Genealogie eines internationalen Konfliktparadigmas. In: Hildebrandt / Brocker (eds), Unfriedliche Religionen?, 39-66.

108 Cf. Hansen, Hendrik, Ein Strukturvergleich von Sayyid Qutbs Islamismus mit Marxismus und Nationalismus. In: Hildebrandt / Brocker (eds), Unfriedliche Religionen?, 67-94. 
for violence in monotheistic revealed religions. ${ }^{109}$ The other parts examine various dimensions and case studies of politically and/or religiously motivated violence. The political ideology of Islamism in different national contexts ${ }^{110}$ is emphasised in this publication.

The need for a differentiated stocktaking of the various discourses emerges from the socio-political relevance of these themes, which is why social and political scientists have focused most recently on the question of the causes of political-religious conflicts. Here, a distinction is made between the so-called 'endogenous' and 'exogenous' causes or the potential for violence and conflict in political theologies. Though Hildebrandt understands the causes inherent to religion to be endogenous, those factors that influence religion from the outside and thus give rise to conflict indicate exogenous causes.

The potential of political theologies for violence and conflict can, according to Hildebrandt, already be grounded in the 'endogenous structure of religious experiences'111 or in the theologies emerging from transcendental experiences. The claim to truth and the claim to a quasi-divine power of definition that underlie the various political theologies entail the danger of fanaticism and the exclusion of others. Another consequence is that the negotiation of religious identity and the identification with the 'in-group' that in turn accompanies the demarcation from the 'religious' other or an 'out-group' entails a significant level of conflict potential. ${ }^{112}$

To understand the causes of political-religious conflict, we must also take their exogenous backgrounds into account. In numerous social-scientific case analyses, various causes of conflict or usually an interplay of different causes could be identified. ${ }^{113}$ If one assumes a 'plurality of underlying motivations'114 in apparently religiously motivated political conflicts, religion represents one of many possible factors that induce this conflict. The identification of a genuine religious motivation behind a conflict therefore requires an extremely differenti-

109 Cf. Walther, Manfred, Strategien der politischen Neutralisierung des Gewaltpotenzials monotheistischer Offenbarungsreligionen. In: Hildebrandt / Brocker (eds), Unfriedliche Religionen?, 95-117.

110 Cf. Derichs, Claudia, 'Form follows function?' Popular Islamic Discourse in Malaysia. In: Hildebrandt / Brocker, Unfriedliche Religionen?, 121-138; Pfahl-Traughber, Armin, Vom Aufbau von Parallelgesellschaften bis zur Durchführung von Terroranschlägen. In: Hildebrandt / Brocker (eds), Unfriedliche Religionen?, 153-178; Hubel, Helmut, Wie viel Religion ist in den Konflikten des Vorderen Orients?, In: Hildebrandt / Brocker (eds), Unfriedliche Religionen?, 179-192. 111 Hildebrandt, Einleitung, 17.

112 Cf. ibid., $19 \mathrm{f}$.

113 Cf. Hildebrandt / Brocker (eds), Unfriedliche Religionen?

114 Hildebrandt, Einleitung, 27. 
ated stocktaking and analysis of all underlying motivations of the participating actors. Because there is usually an overlapping of various motivations, like political, ethnic, social, and religious concerns and religion is frequently instrumentalised by political actors in a conflict, Hildebrandt suggests replacing the concept 'religious conflict' (Religionskonflikt) by the characterisation 'political-religious conflict' (politisch-religiöser Konflikt). ${ }^{115}$ With this, however, he by no means rejects the notion of religion as a trigger of present conflicts and demonstrates that religions usually provoke or reinforce conflicts in those contexts where a claim to monopoly or supremacy is made over against adherents of other religions or the goal is socio-political priority. Moreover, he calls attention to the fact that religion is instrumentalised in numerous conflicts for political goals. ${ }^{116}$

\section{The Return of Religion as Conflict potential?}

In recent years, other authors have also made the theme of religion and conflict the focus of their research. Triggered by the events of 9/11, the perception of religion in research changed more and more. Religiously motivated violence has especially been increasingly thematised in scientific analyses. ${ }^{117}$ Religion is usually cited here as the cause of religiously motivated conflicts or acts of violence. Numerous examples of this can be found in current world politics, including the conflicts between Jews and Muslims in the Middle East, Protestants and Catholics in Northern Ireland, Hindus and Muslims in India, even between the Buddhists and Hindus - both usually viewed as peaceful - in Sri Lanka. There is much talk of the 'power of religions', the 'religious conflicts in world politics'118 or 'terrorism in the name of God'119. In social-scientific discourse on the sociopolitical function of contemporary religions, religion is given the role of promoting conflict. At the same time, however, advocates of the opposite position point

115 Cf. ibid., $27 \mathrm{f}$.

116 Cf. ibid.

117 Cf. Nehring, Andreas, Religion und Gewalt. Ein leerer Signifikant in der Religionsbeschreibung. In: Schweitzer, Friedrich (ed), Religion, Politik und Gewalt. Kongressband des XII. Europäischen Kongresses für Theologie. Munich 2006, 809-821.

118 Röhrich, Wilfried, Die Macht der Religionen: Glaubenskonflikte in der Weltpolitik. Munich 2004.

119 Juergensmeyer, Mark, Terror im Namen Gottes. Freiburg 2004. 
to the peaceful or conflict-reducing aspect of religion in socio-political dynamics. $^{120}$

Already in 1996, Samuel P. Huntington contributed a negative perception of religion to public discourse with his theory of the 'clash of civilizations' ${ }^{121} \mathrm{Al}-$ though his thesis that future conflicts would develop along the boundaries of eight civilizations defined along religious and cultural lines ${ }^{122}$ is viewed as controversial and not tenable empirically, his approach still has wide influence today on the presentation and perception of religion, particularly Islam, as a factor that induces conflict in world politics. ${ }^{123}$ Huntington distinguishes between the Sinic, Japanese, Hindu, Islamic, Christian Orthodox, Western Christian, Latin American, and African cultural regions. ${ }^{124}$ A central identification marker of each region is religion. Huntington sees the conflict potential especially between the Christian West and Islam and thus intensifies the idea of the West as threatened by Islam. ${ }^{125}$

Huntington's approach has been criticised in particular by the sociologist of religion, Martin Riesebrodt. In his 2000 book, Die Rückkehr der Religionen ('The Return of Religions'), Riesebrodt analyses the reinvigoration of religion using the examples from current fundamentalist groups. With his differentiated thesis, he takes a different line than Huntington's view of cultures as monolithic. ${ }^{126} \mathrm{He}$ rejects Huntington's view of cultural spaces or civilisations as marked off from each other by 'blood, language, religion, and lifestyle'127. Riesebrodt criticises the one-sided, monocausal explanation model for religious-political conflicts that Huntington's Clash of Civilizations implies. He points out that a differentiated and systematic approach based on empirical evidence is needed to understand current religious-political conflicts and the conflict potential.

120 Cf. Brocker, Manfred / Hildebrandt, Mathias (eds), Friedensstiftende Religionen? Religion und die Deeskalation politischer Konflikte. Wiesbaden 2008.

121 Cf. Huntington, Samuel P., The Clash of Civilizations and the Remaking of World Order. New York 1996.

122 Huntington is inspired by the so-called cultural circle theory that was coined by the German ethnologist Leo Frobenius.

123 Cf. Brocker, Manfred, Einleitung: Friedensstiftende Religionen? Religion und die Deeskalation politischer Konflikte. In: Id. / Hildebrandt, Mathias (eds), Friedensstiftende Religionen?, 9-25, here 9 .

124 Cf. Riesebrodt, Martin, Die Rückkehr der Religionen: Fundamentalismus und der "Kampf der Kulturen”. Munich 2000, 17.

125 Cf. ibid., 26.

126 Cf. ibid.

127 Huntington, Der Kampf der Kulturen, 52. 
In addition to religious and cultural influences on values, a significant role is played by commercial, political, and social factors like the influence of mass media. ${ }^{128}$ In contrast to Huntington, Riesebrodt points to the beneficial aspects of religion as 'potential for identity formation and solidarity'129.

\section{Religions' Potential for De-escalating Conflicts?}

As far as the connection between religion and conflict is concerned, social-scientific studies - as already demonstrated - have usually dealt with the factors of religion that trigger and promote conflict. Current studies, however, have neglected the investigation of the effects of religion that hinder and de-escalate conflict.

Here the work Friedensstiftende Religionen? Religion und die Deeskalation politischer Konflikte ('Peacebuilding Religions? Religion and the De-Escalation of Political Conflicts' $)^{130}$ is to be especially emphasised. The first part of this three-part volume discusses theological discourse. Here it traces, from the perspective of current theologies, the assumptions that religions contain the potential for resolving conflicts and peacebuilding. Using various examples, authors like Mathias Hildebrandt, Thomas Fuchs, Uwe Voigt, and Reinhard Sonnenschmidt look at religious dialogue in European religion in the past and present. In the first contribution Hildebrandt points to the Christian encounter with other religious ideas in the Middle Ages through written religious dialogues. The written testimonials demonstrate strategies and the purpose of religious dialogue. According to Hildebrandt, they served to defend and strengthen Christian doctrines by means of rational arguments over against other competing religions (in particular Judaism, Islam, and Christian 'heresies'). ${ }^{131}$

Looking at the Reformation, Thomas Fuchs explores the question of dialogue as a conflict management strategy. ${ }^{132}$ Uwe Voigt also deals critically with religious dialogue or interreligious dialogue and refers to the example of the theologian Johann Amos Comenius on the necessity of knowing one's own religion as

128 Cf. Riesebrodt, Die Rückkehr der Religionen, 14.

129 Ibid.

130 Brocker / Hildebrandt, Friedensstiftende Religionen?

131 Cf. Hildebrandt, Mathias, Mittelalterliche Religionsdialoge: Auf der Suche nach einer interreligiösen Hermeneutik. In: Brocker / Hildebrandt (eds), Friedensstiftende Religionen?, 29-70. 132 Cf. Fuchs, Thomas, Reformatorische Auseinandersetzungen in der Stadt. Das Religionsgespräch der Reformationszeit als Konfliktlösungsstrategie. In: Brocker / Hildebrandt (eds), Friedensstiftende Religionen?, 71-84. 
well as the other's for entering into dialogue. ${ }^{133}$ In distinction from the first three authors, who approach conflict and peace from a historical perspective, in the last contribution Reinhard Sonnenschmidt analyses the problem of dialogue with contemporary religious fundamentalists. ${ }^{134}$

In the second part of the book, the ability of religions to engage in dialogue on the theoretical level is analysed. Peter Koslowki links up here with theological discussions on the philosophy of revelations and situates the source of religion in the human need to overcome contingency. He distinguishes in this context between two basic categories of religion, namely 'retribution' and 'revelation'. ${ }^{135}$ Retribution is related to the human need for righting injustices, whereas the hope for retribution is grounded in revelation. Starting from the perspective that both of these aspects underlie the Abrahamic religions, the author discusses connecting and exclusionary features of these religions. Whereas the idea of the one God who has manifested himself in various times and in various contexts can be used as an identification marker, there is on the other hand the problem of the claim to absoluteness. This claim is inherent in the current monotheistic theologies and constitutes a challenge for interreligious dialogue. ${ }^{136}$

A political or social-scientific perspective is presented in the contribution by Mark Arenhövel and Andreas Hasenclever. Following current discourses in the social sciences, Arenhövel links up with the concept of the 'postsecular' and discusses the problem of diverging worldviews on the basis of the growing religious plurality that has been diagnosed in contemporary Western societies. ${ }^{137} \mathrm{He}$ shows the importance here of active religious actors in political debates on the maintenance of peace within the state. ${ }^{138}$

Andreas Hasenclever provides an important contribution to the understanding of religious-political conflicts with his empirically oriented analysis of the

133 Cf. Voigt, Uwe, ,Allen alles auf allseitige Weise lehren“ (Johann Amos Comenius). Das Menschenrecht auf Bildung als Bedingung und Inhalt eines interreligiösen Dialogs. In: Brocker / Hildebrandt (eds), Friedensstiftende Religionen?, 85-97.

134 Cf. Sonnenschmidt, Reinhard W., Dialog der Religionen? Das Modell Eric Voegelins: ,The Christian idea of mankind‘ oder ,Gnostizismus als Wesen von Modernität‘? In: Brocker / Hildebrandt (eds), Friedensstiftende Religionen?, 98-107.

135 Cf. Koslowski, Peter, Der Dialog der Weltreligionen und die Philosophie der Offenbarungen. In: Brocker / Hildebrandt (eds), Friedensstiftende Religionen?, 111-122.

136 Cf. Brocker, Einleitung: Friedensstiftende Religionen?, $15 \mathrm{f}$.

137 Cf. Arenhövel, Mark, Über das Befriedungspotential der Religion in den ,postsäkularen Gesellschaften'. In: Brocker / Hildebrandt (eds), Friedensstiftende Religionen?, 158-178.

138 Cf. Brocker, Einleitung: Friedensstiftende Religionen?, 18. 
course of political conflicts. ${ }^{139}$ He demonstrates that there are, generally speaking, political or economic factors behind wars that are considered to be religiously motivated. Religion or religious motives are construed by the actors to justify their political or commercial interests. But religion, according to Hasenclever's thesis, influences the course of such political confrontations as either impeding violence or intensifying conflict. As a result of empirical studies, the engagement especially of religious peacebuilding actors influences the course of conflicts away from violence. ${ }^{140}$

The third part of this book clarifies the peacebuilding potential of religions via various case studies from the history and present state of religion like the conflicts in Northern Ireland ${ }^{141}$ or in the Middle East ${ }^{142}$. The above-mentioned authors demonstrate the role of religion in political confrontations by means of examples and concretise these via numerous empirical proofs.

The clarification of whether religion functions to build peace or to promote conflict and disintegration is based on a 'functional' view of religion that is oriented to what religion brings about or which societal function religion fulfils. ${ }^{143}$ At the same time, the question of the religious causes of conflict also implies a substantialist or essentialist concept of religion that looks for the 'essence of religion'. From the perspective of religious studies, both cases display a narrow concept of religion from which religious studies research has distanced itself in recent years. ${ }^{144}$ From a theological point of view, one can see that the fault lines of the conflict between religious studies, sociology, and theology follow precisely the question of a functionalist or substantialist treatment.

139 Cf. Hasenclever, Andreas, Merkmale gewaltresistenter Glaubensgemeinschaften -Überlegungen zum Schutz religiöser Überlieferung vor politischer Vereinnahmung. In: Brocker / Hildebrandt (eds), Friedensstiftende Religionen?, 179-201.

140 Cf. ibid.

141 Cf. Moltmann, Bernhard, Irritationen des Friedens. Die nordirischen Kirchen auf der Suche nach ihrer Rolle als Friedensstifter. In: Brocker / Hildebrandt (eds), Friedensstiftende Religionen?, 246-268.

142 Cf. Scheffler, Thomas, Dialog und Dialog, Frieden und Frieden: Zur Ambivalenz von interreligiösem Dialog und Friedensarbeit im Nahen Osten. In: Brocker / Hildebrandt (eds), Friedensstiftende Religionen?, 284-298.

143 Cf. Hock, Klaus, Einführung in die Religionswissenschaft. Darmstadt ${ }^{3} 2008,16$.

144 Comprehensive representations of the conceptualisations and current discourses in religious studies are found, for example, in Bergunder, Michael, Was ist Religion? Kulturwissenschaftliche Überlegungen zum Gegenstand der Religionswissenschaft. In: Zeitschrift für Religionswissenschaft (2011) 1/2, 3-55. 


\subsubsection{Conflict and the Conflict Potential from the Perspective of Theology and Religious Studies}

\section{Approaches to the Relation between Religion and Conflict}

The question of the connection between conflict and religion from a theological and philosophical perspective was the focus of the volume published in 2011 and edited by Ingolf U. Dalferth and Heiko Schulz: Religion und Konflikt. Grundlagen und Fallanalysen ('Religion and Conflict: Foundations and Case Studies'). ${ }^{145}$ This volume looks at the theme from the perspective of the sacred scriptures of Islam, Christianity, and Judaism. In particular, Dalferth and Schulz examine the problematic claim to absoluteness by monotheistic religions. Dalferth introduces the volume by discussing preliminary considerations about religions and conflicts in terms of a hermeneutics of conflict. He refers to different perspectives from which the question of religion and conflict can be posed. In his opinion, religions are themselves conflict phenomena, both 'in their external relation to each other' and 'in their internal structure ${ }^{146}$. According to Dalferth, religions will inevitably lead to conflict if they are perceived as value orientations for a certain way of life. ${ }^{147}$ The co-existence of people from different religions subsequently leads unavoidably to conflict. But tension internal to a religion can also cause conflict. On the one hand, conflicts can arise between religious and nonreligious alternatives. On the other hand, every fundamental tension with respect to religion is grounded in its acts of symbolising a transcendent power, which also manifests itself in the language of religion:

By speaking of the undefinable by means of the defined and definable, religions generate differences, distinctions, tensions, and paradoxes that are not distinctions in the definable and between phenomena ... but they symbolise and variegate the fundamental distinction between definable phenomena and the undefinable in the definable (in language and in the performed cultic actions). ${ }^{148}$

Dealing with the contingency of human life via religion and the experience of uncertainty and indefinability presents a fundamental conflict here. ${ }^{149}$ First, there is the conflict between the world of human experience and the world of

145 Dalferth, Ingolf U. / Schulz, Heiko (eds), Religion und Konflikt. Grundlagen und Fallanalysen. Göttingen 2011.

146 Dalferth, Ingolf U., Einleitung. Religionen und Konflikte. Konflikthermeneutische Vorüberlegungen. In: Dalferth / Schulz (eds), Religion und Konflikt, 9-22, here 11.

147 Cf. ibid.

148 Ibid., 15.

149 Cf. ibid., $16 \mathrm{f}$. 
the transcendent. But the alternative world posed by religion is, for its part, already charged with conflict, which emerges from the example of the discrepancy between heaven and hell in Christian understanding. As a consequence, religions are characterised by insurmountable challenges that imply an internal conflict potential. ${ }^{150}$

Fundamental questions of the theory of religion and conflict are discussed by various authors on different levels. Heiko Schulz first outlines a framework for religious conflicts on the basis of the clarification of the concept of religion. He distinguishes between religion as an institutional aspect and religiosity as an attitudinal aspect. ${ }^{151}$ According to Schulz,

only what is understood, said, or done phenomenologically as an expression or name for something like religion (alternatively: God, Christianity, true faith or something similar) can be said to be religious. ${ }^{152}$

If experiences, attitudes, or actions are characterised as religious, they can subjectively be treated as religious. In the first instance, one thus encounters the distinction as to whether a conflict can be classified as genuinely religious or not. ${ }^{153}$ The presupposition here, however, is that 'the truth of conflict-generating beliefs is also irrelevant for the constitution of the character of the conflict in question'154.

Gesche Linde sketches a theory of action that grounds religion theoretically as a 'theory of implicit sociality' that can be used for understanding religious conflicts and their regulation. ${ }^{155}$ Making use of the semiotic theory of action, Linde first defines her concept of conflict and describes, by means of the example of the history of the Christian religion the extent to which religion represents a reason or occasion for conflict.

We should also mention Stephan Sellmaier here, who developed a theory of the 'ethics of conflict'. ${ }^{156}$ Based on this theory, a connection between religion

150 Cf. ibid., $20 \mathrm{f}$.

151 Cf. Schulz, Heiko, Sind Religionen konfliktfähig? Vorüberlegungen zum themenspezifisch relevanten Begriffsfeld. In: Dalferth / Schultz (eds), Religion und Konflikt, 23-46, here 37.

152 Ibid., 39.

153 Cf. ibid., 41.

154 Ibid.

155 Cf. Linde, Gesche, Religion als implizite Sozialitätstheorie. Eine handlungstheoretische Skizze. In: Dalferth / Schultz (eds), Religion und Konflikt, 47-84.

156 Sellmaier, Stephan, Ethik der Konflikte. Über den moralisch angemessenen Umgang mit ethischem Dissens und moralischen Dilemmata. Stuttgart 2008. 
and conflict can be posed and a distinction can be made between narrow and broad dissent. ${ }^{157}$ Dissent in the narrow sense exists, according to Sellmaier, if

an honest normative judgment of a religion that is thought through on a fundamental level and contains a truth claim contradicts a similar judgment by another religion about a concrete and clearly defined crucial situation. ${ }^{158}$

But this seldom exists in ideal forms in political contexts. Much more often, 'religious dissent in the broad sense'159 can be identified: 'dissent concerning the appropriate presentation and recording of an ethically relevant situation. ${ }^{160}$

\section{Violence and Conflict in Religions}

The connection between religion and conflict is examined from various perspectives especially in religious studies. Here the question of the religious roots of conflict is often the focus. With reference to the analysis of the religious studies scholar, Andreas Nehring, ${ }^{161}$ the most common explanatory models will be presented below. These are 'religion as a fundamental source of conflict', 'violencepromoting religions vs peaceful religions', and 'religion as such has no connection with violence'.

A very common explanatory model understands religion as a fundamental source of violence. The biblical verse Hebrews 9:22 is often used here as a point of contact: 'In fact, the law requires that nearly everything be cleansed with blood, and without the shedding of blood there is no forgiveness.' This view can also be found in Mikhail Bakunin's work (published in 1871) God and the State, to demonstrate the ambivalence of the sacred and the cruelty that underlies the essence of religion. He sees the ambivalence of the sacred grounded in the fact that religious people have to bring sacrifices. People had to offer a sacrifice to a vengeful, ambivalent God. To speak of the ambivalence of the sacred refers, according to Nehring, to a discursive religious studies praxis

that does not purely present or depict an allegedly always present reality, Rather, it is itself effective by producing for the academic discourse only what characterises it. ${ }^{162}$

157 Cf. Sellmaier, Stephan, Enger und weiter religiöser Dissens. In: Dalferth / Schulz (eds), Religion und Konflikt, 85-100.

158 Ibid., 87.

159 Ibid., 94.

160 Ibid.

161 Cf. Nehring, Religion und Gewalt.

162 Ibid., 814. 
Nehring sees the field of tension between 'violence-promoting religions and peaceful religions' as a second model. Eastern religions, like Hinduism and Buddhism, which are often seen as peaceful, tolerant, and spiritual, are contrasted with violence-promoting, intolerant monotheism. ${ }^{163}$

The last current explanatory model that, according to Nehring, dominates this debate is the idea that religion and violence are incompatible. This - in his view - apologetic justification consists in the assertion that religion has a noble and peaceful core that has nothing to do with violence and conflict. ${ }^{164}$

In this essay, Nehring points out that, on the one hand, these explanatory models all draw on the assumption of an essence of religion. On the other, in each case, religions are ascribed features that reflect the intentions of its respective 'spokespersons'. A religion like, for example, Christianity can be presented as both peaceful and as promoting violence. Violence, like conflict potential, is not a natural, essential feature of religion but is construed in concrete, usually political situations. Nehring therefore proposes a non-essentialist approach to the religious studies analysis of this discourse, arguing for carrying out a careful historicisation of the conceptualisation of this discourse in order to reveal the power constellations and intentions behind it. ${ }^{165}$

Another access to the theme of religion and violence has been made by the cultural anthropologist and philosopher of religion, René Girard, who investigated the development of religions and rites in the archaic world in dealing with destructive violence between individuals. This violence grows out of the potential for violence that underlies human desire. Girard describes the human being as primarily determined by his desire, which is based in mimesis, i.e., the imitation of a usually unconscious example that serves as a model. Through this process of mimesis, the desire of the imitator and imitated (the model) is directed at the same object. If this is available in only a limited way, a rivalry arises because of the mimesis: the model becomes a rival. ${ }^{166}$

163 Cf. ibid., 815; moreover, the work of the religious studies scholar Michael Bergunder on Hinduism and violence (Bergunder, Michael, Hinduismus und Gewalt. In: Biehl, Michael (ed), Gottesgabe. Vom Geben und Nehmen im Kontext gelebter Religion. Festschrift zum 65. Geburtstag von Theodor Ahrens. Frankfurt/Main 2005, 215-237) as well as an issue of the Zeitschrift für Religionswissenschaft zu Buddhismus und Gewalt (Zeitschrift für Religionswissenschaft [2003], Nr. 2) have contributed to the deconstruction of this debate.

164 Cf. Nehring, Religion und Gewalt, 815.

165 Cf. ibid., 817.

166 Cf. Girard, René, Figuren des Begehrens. Das Selbst und der Andere in der fiktionalen Realität. Vienna ${ }^{2} 2012,11-58$. 
This conflict potential, which is present in the mimetic desire underlying human nature, threatens human society if violence is not curbed or suppressed. In communities in the archaic world, according to Girard, there were mechanisms that reined in this mimetic rivalry through ritualisation and the divinisation of the sacrificial cult. The social crisis that violence caused

led to the mimetic sacrifice mechanism to form the first systems of prohibitions and sacrificial rites. These were the first religions and they formed the initial form of human culture. ${ }^{167}$

Girard thus presents the rise of the first religions in his work and traces the development of human dealing with the potential of mimetic desire for conflict through the biblical writings. He situates the high point of this in the gospels where Jesus becomes the model of a positive mimesis. The dynamics of the mimetic rivalry are revealed in the narratives and transformed in the actions of Jesus. ${ }^{168}$ Jesus frees himself from the dynamics of mimetic rivalry by renouncing the violent implementation of his objectives and orients his desire to higher goals: life, peace, and happiness.

Influenced by biblical tradition, Girard emphasises Jesus as the turning point in human history with respect to dealing with mimetic desire. The Christian theologian Wolfgang Palaver points out that the continuity in Girard's expositions on a positive handling of mimetic desire lies 'in a mystical attitude'169 that entails a rejection of egoistic individualism and the violence-prone implementation of one's own beliefs. That opens up a way of reconciliation and peace that, in Palaver's view, is emphasised in the demonstration of the central place of the mystical attitude found in different religious traditions, also outside Christianity. ${ }^{170}$

The directions for such an attitude can be found, for instance, in the Islamic scholar and mystic Abu Hamid al-Ghazali (d. 1111). In his work, al-Ghazali emphasises the significance of renunciation for rejecting inhuman violence: 'So, the anger of him whose need is greater will be greater and he will be more help-

167 Girard, René, Gewalt und Religion: Ursache oder Wirkung? (edited by Wolfgang Palaver). Berlin 2010, 15.

168 Cf. Girard, René, Ich sah den Satan vom Himmel fallen wie einen Blitz. Eine kritische Apologie des Christentums. Munich 2008, 156-192.

169 Palaver, Wolfgang, Girard und Hölderlin: Die Bedeutung der kenosis für Girards apokalyptisches Denken. In: Guggenberger, Wilhelm / Palaver, Wolfgang (eds), Eskalation zum Äußersten? Girards Clausewitz interdisziplinär kommentiert. Baden-Baden 2015, 135-155, here 135.

170 Cf. ibid. 
less and impoverished; for freedom lies in needlessness. ${ }^{\text {,171 }}$ Al-Ghazali can be a point of contact in the Islamic tradition for Girard's mimetic theory. There are, according to Palaver, such instructions for an abjuring attitude, also in the mystical traditions of, for example, Christianity, Judaism, and Eastern religions. ${ }^{172}$

Girard's theory allows the discovery of points of contact in different religious traditions that show a positive approach to mimetic desire and a rejection of violence. For the relation between religion and violence or conflict, Girard's thinking is relevant primarily with respect to the significance of religious norms and rites. In his view, these norms and rites can keep the existing violence and conflict potential in check. Furthermore, there are models and instructions in religions, especially in the mystical traditions, that provide instructions for a path to reconciliation and peace. By way of example, Kerstin Kellerman also presents a theological-Christian perspective that grounds the potential for a peaceful dialogue in the ethic of love in Christianity. ${ }^{173}$

The Center for Comparative Theology and Cultural Studies at the University of Paderborn also emphasises the thematic area of religion and violence. Hamideh Mohagheghi in particular does that from a Muslim perspective. In the current context of religious fundamentalism and extremism, she considers a reflective analysis on the relation between religion and violence to be necessary. From her perspective, it is crucial that adherents and teachers of these religions have a clear view of the problematic areas of their own religions and deal with them. In the present increasing turn to 'clarity in beliefs', for Islamic theology this means reviving the tradition of iğtihād (concern with new doctrines anchored in the tradition). ${ }^{174}$

\section{Religion and Conflict in Interreligious Education}

Our discussion until now has adequately shown that there is conflict for potential in the encounter between people who have been socialised in different ways religiously and culturally, particularly on the macrolevel. But the question of re-

171 Al-Ghazali, On the Treatment of Anger, Hatred and Envy. (Translation by Muhammad Nur Abdus Salam). Chicago 2002, 10.

172 Cf. Palaver, Girard und Hölderlin, 139.

173 Cf. Kellermann, Kerstin, Christus - Stein des Anstoßes: Über ,kulturelle Friedfertigkeiten jenseits von Siegerlogiken in Religion und Politik. In: Brocker / Hildebrandt (eds), Friedensstiftende Religionen?, $138-157$.

174 Cf. Mohagheghi, Hamideh, "Tötet sie, wo ihr sie trefft." - Eine Auslegung zu Q 2:190-195. In: Ead. / von Stosch, Klaus (eds), Gewalt in den Heiligen Schriften von Islam und Christentum. Paderborn 2014, 73-91, here 73-75. 
ligiously determined conflict potential has become more and more significant in recent years in the field of religious education as well, even though it is not explicitly thematised.

Here we look once again at the international REDCo project that we discussed above. The goal of this project is 'to establish and compare the potential and limitations of religion in the educational fields of selected European countries and regions. ${ }^{175}$ The project included various disciplines like theology, Islamic studies, educational sciences, sociology, political science, and ethnology. It also engaged in historical and contemporary analyses combined with each other in order to work out the factors that promote interreligious dialogue in the area of education. ${ }^{176}$

In addition to the openness of the students to other religions, in the research project, 'structures of prejudices towards other religions ${ }^{\text {'177 }}$ became clearly visible. What still remains, however, is a detailed investigation of the extent to which religion and religiosity are determinants of prejudice and conflict.

Furthermore, we would also like to refer here to the online journal for intercultural studies, Interculture Journal. In the ninth issue, Interkulturalität als Gegenstand in Lehre, Training, Coaching und Consulting ('Interculturality as a Subject in Teaching, Training, Coaching and Consulting'), challenges and objectives of interculturality are described by various authors. Any references to conflict are found here between the lines. In particular, the contribution by Joachim Willems Interreligiöses und interkulturelles Lernen: notwendige Bezüge und notwendige Unterscheidungen ('Interreligious and Intercultural Learning: Necessary References and Necessary Distinctions') is relevant for our topic. In both intercultural and interreligious education, plurality is perceived as a problem or challenge, ${ }^{178}$ which, according to Willems, also consequently emerges in the area of intercultural and interreligious learning. One objective of interreligious learning is to get to know adherents of other religions and to treat their different views with respect and recognition. The fundamental assumption here is 'the clarification

175 Weiße, Wolfram, Interreligiöse Bildung in Europa. In: epd-Dokumentationen (2009) 20, 12-14, here 13. For the English translation, see: https://cordis.europa.eu/project/id/28384/reporting, [last accessed: 09.09.2019].

176 The final report can be found on the following website: https://cordis.europa.eu/result/rcn/ 47525_en.html, [last accessed 10.09.2018].

177 Weiße, Interreligiöse Bildung in Europa, 14.

178 Cf. Willems, Joachim, Interreligiöses und interkulturelles Lernen: notwendige Bezüge und notwendige Unterscheidungen. In: interculture journal. Online-Zeitschrift für interkulturelle Studien (2009) 9, 23-44. 
and awareness of one's own moral concepts, identities, and worldviews' ${ }^{179}$ as well as being occupied with other cultures. Here, the ability to engage in metacommunication and to show empathy and to acknowledge others is necessary. The objectives of intercultural education therefore lie in the revealing and thematisation of discrimination and racism, promoting solidarity, and preventing further conflicts. ${ }^{180}$

Willems therefore holds that a 'general objective' of interreligious and intercultural learning is 'to deal with other worldviews'181 and 'to find ways to balance interests and to reflect to some extent on the foundations and process in order to arrive at such a balance. ${ }^{182}$ It is important to clarify whether conflicts should be seen as intercultural, interreligious, social, legal, etc. For that, it would be helpful to analyse and investigate processes of ascription. ${ }^{183}$ Willems also points beyond that to a need to connect intercultural and interreligious learning in order to counteract stereotyping, culturalisations, ethnicisations, or religionisations because concepts like 'culture' and 'religion' are reflected in them. ${ }^{184}$

Finally, we should also mention here the Innsbrucker Forschungszentrum Religion - Gewalt - Kommunikation - Weltordnung (Innsbruck Research Centre of Religion - Violence - Communication - World Order; RGKW), which consists of two research programmes: Dramatic Theology or Mimetic Theory, and Communicative Theology. The centre focuses on questions of the connection between theology and church and between theory and praxis. In the research programme of dramatic theology, questions of religion and violence are central to theological research. The research programme of Communicative Theology is concerned with theological and religious educational processes from the perspective of theme-centred interaction (TCI). There R. C. Cohn's interactional method of learning as

sharing and compassionate teaching and learning ... is removed from the straitjacket of a purely material approach to knowledge into a holistic approach that is oriented to a humanisation of society. ${ }^{185}$

179 Ibid., 32.

180 Here Willems refers to a monograph by Nieke, Wolfgang, Interkulturelle Erziehung und Bildung. Wertorientierung im Alltag. Opladen ${ }^{2} 2000$.

181 Willems, Interreligiöses und interkulturelles Lernen, 37.

182 Ibid.

183 Cf. ibid.

184 Cf. ibid., 34-44.

185 Scharer, Matthias, Begegnungen Raum geben. Kommunikatives Lernen als Dienst in Gemeinde, Schule und Erwachsenenbildung. Mainz 1995, 35. 
Teachers in theme-centred learning groups thus look at a 'dynamic balance between the Globe, I, We [and] It, ${ }^{186}$ whereby particular conflicts or disruptions that arise in interactions are revealed and discussed. ${ }^{187}$

The idea for this project is thus due not least to this conflict-sensitive approach to learning and teaching, especially in interreligious encounter. Even though we could show here that in recent years various disciplines have turned to the analysis of the relation between religion and conflict, especially on the macrolevel, there is also a gap in research on the microlevel, on the level of interaction between individuals, as we see in the area of education. In our view, there is a desideratum for research particularly in empirical research into interreligious conflicts. By building on existing social-scientific studies and theological considerations, we intend to lay another building block for understanding the relation between religion and conflict through an empirical investigation into interreligious educational processes and the concomitant conflict potential emerging from them.

186 Ibid.; the concepts 'I', 'We', 'It', and 'Globe' are also known as the TCI triangle. Whereas 'I' refers to individuals with their respective biographies and 'We' to the interactions and relationship structure of the group, the 'It' refers to the content that is focused on, or the task that is to be handled by the group. 'Globe', in turn, refers to the surroundings that influences the group and, conversely, is influenced by the group (cf. Sejdini / Kraml / Scharer, Mensch werden, 87). 187 Cf. Scharer, Begegnungen Raum geben, 35; on this, cf. also: Scharer, Matthias, Der Universitätslehrgang "Kommunikative Theologie" als Modell theologisch inspirierten Konflikt- und Versöhnungshandelns. In: Schwager, Raymund / Niewiadomski, Józef (eds), Religion erzeugt Gewalt - Einspruch! Innsbrucker Forschungsprojekt ,Religion - Gewalt - Kommunikation Weltordnung. Münster 2003, 273-286. 